\title{
Ageing in Europe
}

For many people all over Europe, there is an understanding and an expectation that in old age they will be taken care of by the state. High social security contributions throughout the three or four decades of a working life are rationalised by the prospect of a straightforward transition out of the labour force when the time comes. While this was a reasonable expectation in decades past, a number of factors have combined to cause people all across the continent to feel very anxious about what awaits them once it is time to exit the labour force into retirement. The well-documented demographic transition of many rich European countries is a big factor, as greying populations start to weigh on the sparser younger generations, leading to increasing dependency ratios that would cause any social security system to buckle. The Great Recession has not helped matters, and the austerity measures still crippling many vulnerable European nations will not make anyone in these countries feel optimistic about their post-working lives. The following papers look at different threads of the new reality of ageing in Europe, from pension reform and prolonging the working life to more qualitative aspects such as an analysis of the quality of life of the elderly across Europe. They serve to inform and advise on an important issue that will affect everyone in Europe at some point in their lives.

\section{Financial Literacy and Preparation for Retirement}

Henriette Prast, Tilburg University; and Netspar, Tilburg, The Netherlands.

Arthur van Soest, Tilburg University; and Netspar, Tilburg, The Netherlands.

Why Is Austria's Pension System So Much Better Than Germany's?

Florian Blank, Hans Böckler Foundation, Düsseldorf, Germany.

Camille Logeay, University of Applied Sciences (HTW), Berlin, Germany.

Erik Türk, Vienna Chamber of Labour, Austria.

Josef Wöss, Vienna Chamber of Labour, Austria.

Rudolf Zwiener, Hans Böckler Foundation, Düsseldorf, Germany.

The 2015 Pension Adequacy Report's Examination of Extended Working Lives as a Route to Future Pension Adequacy

Fritz von Nordheim, European Commission, Brussels, Belgium.

\section{Extending Working Lives - Sticks and Carrots to Get the Older Unemployed Back into} Employment

Jürgen Bauknecht, TU Dortmund University, Germany.

Andreas Cebulla, University of Adelaide, Australia; and National Institute of Economic and Social Research, London, UK.

\section{New Evidence on Active Ageing in Europe}

Alan Walker, University of Sheffield, UK.

Asghar Zaidi, University of Southampton, UK. 